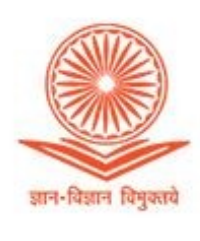

\title{
FACTOR AFFECTING THE PERFORMANCE OF MUTUAL FUNDS
}

\author{
Miss. Kiran Khinchi \\ Dr. Monty Kanodia
}

\begin{abstract}
Buying a Mutual Fund is a complex process because it is a complex decision one individual can make as Mutual fund involves risk. Mutual fund returns being affected by the fluctuation of many internal and external factors of the industry. This paper is mainly highlighted and explored the internal and external factors or schemes specific and macro-economic factors which influence the performance of mutual fund performance directly or indirectly. As a beginner in capital market it is very difficult to understand and to invest in it. One should be well aware about the risk involved while investing in the mutual fund. This study is an attempt to come over the difficulty faced by an individual while investing in the mutual fund. Study tried to explore few attributes or factors which should be considered before investing in a fund.
\end{abstract}

Keywords: Mutual Funds, Macroeconomic Variables, Schemes Specific Variables.

\section{Introduction}

Mutual Fund industry has grown over the last few years, the by rises and restraints. Fund industry AUM has grown above 40\% fromseventeen trillion in 2017March -twenty-five trillion in July 2019. Throughout the dated, contributionsof monthly basedSIP have almost gathered from $4,335 \mathrm{Cr}$. a month to $8,324 \mathrm{Cr}$. a month, which reduces thereliance on FIIS.India ranked 7 th in terms of GDP, and ranks $17^{\text {th }}$ inMutual Fund Assets Under management. In a country having population around 1.3 billion people, only $2 \%$ individuals invest in mutual funds; whereas in developed countries like US this figure is plentiful higher. Evidently, the Mutual Fund industry has anelongated way to go.Though Indians are gradually moving away from physical savings to financial savings, they realized that to beat economic inflation it is much required to change their traditional saving options to stock, equities and mutual funds at a much slower pace. Since so many fluctuations exist in the Mutual Fund Market and much risk is involved in it, it creates an impulse to study about those reasons which are liable for the ups and downs in the Industry. The mindfulnessoperation, 'Mutual Funds Sahi Hai', is a pace in that way and has seen with pretty a bit of success, it will take time for entrenchedbehaviors to variation. 
Towards Excellence: An Indexed, Refereed \& Peer Reviewed Journal of Higher Education / Ms. Kiran Khinchi \& Dr. Monty Kanodia/ Page 43-51

Present study aims to study the reasons and factors which are associated or related to mutual fund performance. Which are directly or indirectly affecting the performance of the mutual fund. In this research we have focused Indian mutual fund industry as well as rest of the world.

There is clearness in the running of funds all the pertinent information is available openly, and it's up to the individual whether one can use this information effectively and profitably. Attributes or characteristics which influences the performance is less explored, very less factors are covered. There are many reason that should be considered before buying any schemes. An individual can also make profit out of the schemes if he/she evaluate or consider few variables that affects the performance directly or indirectly.

\section{Evolution of Mutual Fund Industry}

Figure 1. Evolution of Mutual Fund Industry

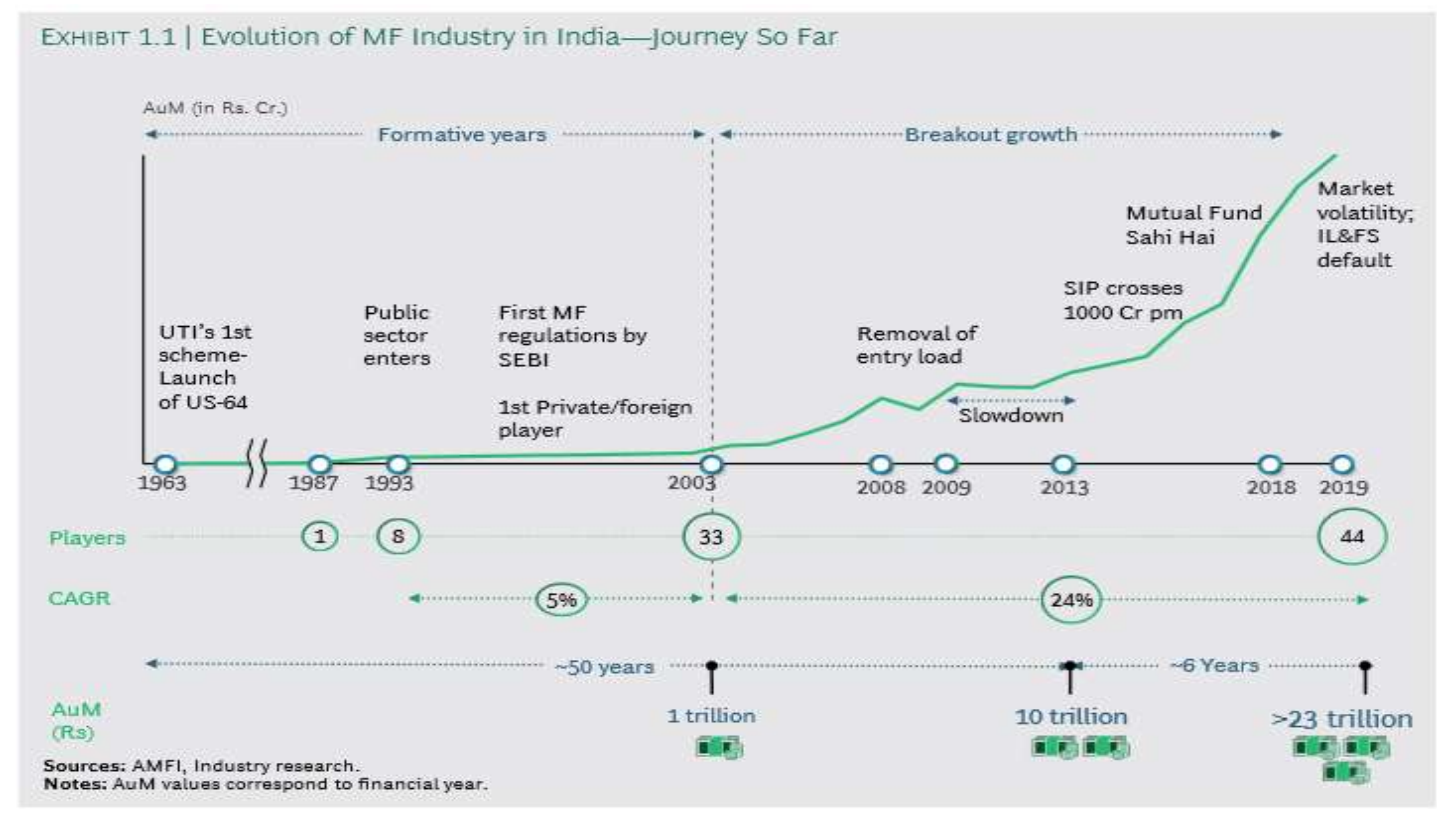

Source:

AMFI, Industry Research

1963: Unit Trust of India, a single Indian Mutual Fund entity.

1987-1993: 8 new funds launched by banks, LIC and GIC.

Total number of Schemes reached to 167 .

AUM grows to ₹ $6700 \mathrm{Cr}$.

AUM shoots up to ₹ $61000 \mathrm{Cr}$.

Entry of foreign and private players.

First entrant was Kothari Pioneer. 
Towards Excellence: An Indexed, Refereed \& Peer Reviewed Journal of Higher Education / Ms. Kiran Khinchi \& Dr. Monty Kanodia/ Page 43-51

1996: SEBI formulated Mutual Fund regulations.

2014: 45 Mutual Fund Organization in the market.

Asset Under Management reached near to ₹ 10 Lakh Cr.

\section{Merits of Mutual Funds}

Easy \& instant Divergence: One principle of safe investing is to extent money across altered options. MF are an easy way to do this. Spread of money across large number of Investment options.

Convenience: One can effortlessly make investment and withdraw any amount that we like. Investments can be done by simple form filling or by online with direct debit from bank account.

Tax Efficiency:While buying or selling any investment, one has to pay tax on the profit earned. However, this doesn't happen that buying or selling is done on one's behalf of a mutual fund. To maximize profits, the fund manager could keep buying and selling stock as needed, but one has to pay tax only when investment has to be redeemed from the fund.

Professionally Managed: Literally hundreds of companies to follow and one's perspective could change without notice. Mutual funds employ full time professional investment managers and research workforce. This cost and efforts get pooled "mutually" among all the investors.

Transparent and well Regulated: Mutual funds are required by law to disclosefullinformation about theiractivities and investments. Almost all funds release net asset values daily and most releases full portfolios every month. The SEBI regulates the fund industry very strictly and is constantly refining the applicable rules in order to better protect investors.

Figure 2. Mutual Fund Returns 


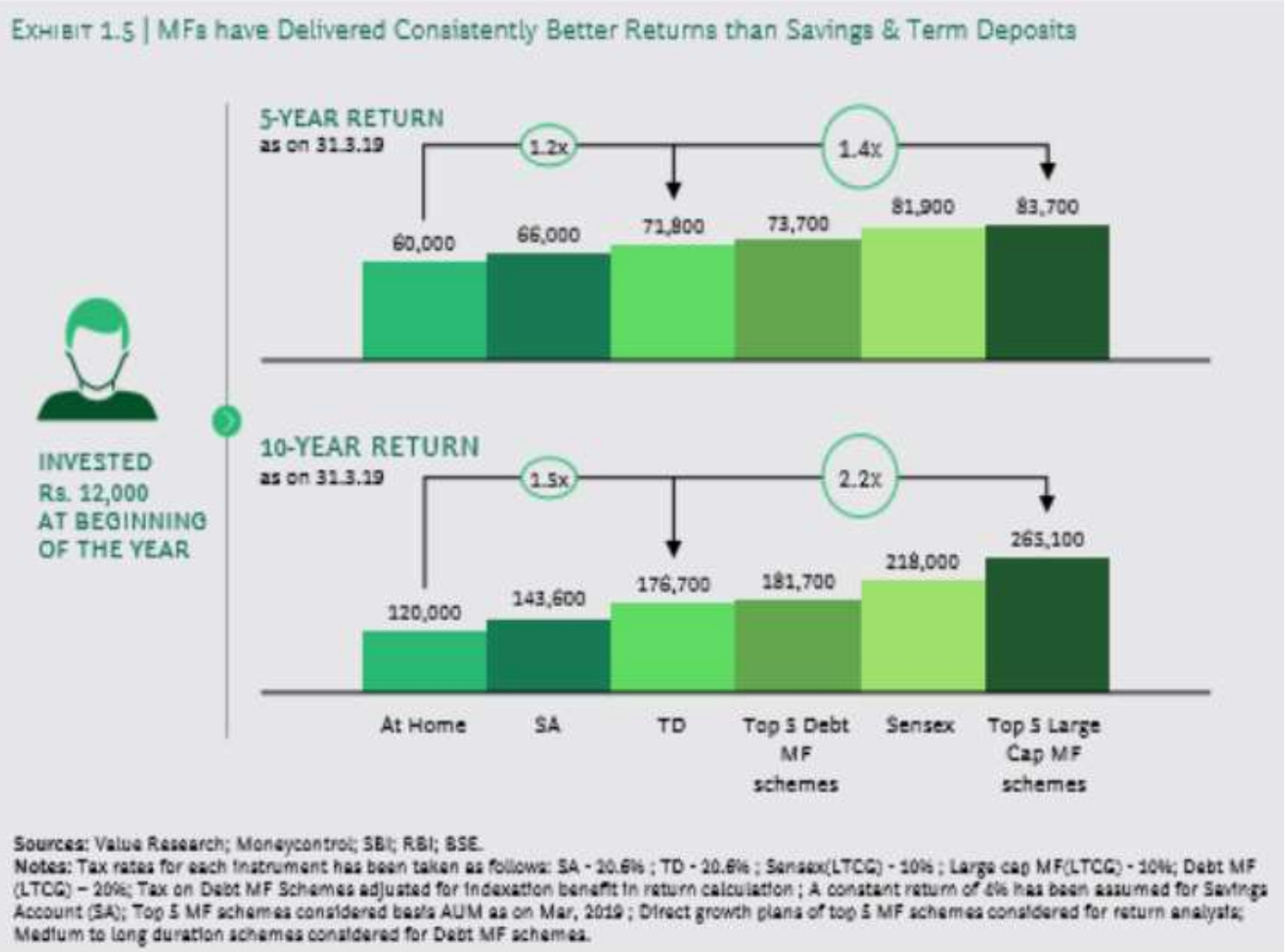

Source: Value Research; Money Control;SEBI;RB

\section{Review of Literature}

Sharpe (1966) in an investigation into the relationship between risk and the return found a positive relationship. Locally, Murithi (2005) estimated the risk return relationship of equity mutual funds and found a positive relationship between the two factors.Berk and Green (2004) debated out why past performance should not predict future performance.Pollet and Wilson (2008) examine influences that could lead to diseconomies of scale which in turn increase the expenses.Chan et al (2002) in their article to analyze whether differences in style are associated with differences in performance have adopted a style classification based on two dimensions: market capitalization and value-growth orientation also confirm that size (small, mid, and large) and book-to-market (value, growth) are useful descriptors of fund stylesBrown and Goetzmann (1997), Carhart (1997) display that size and cost help account for differences in fund performance.Grinbalt and Titman (1989), Daniel et al. (1997) used asubstitute approach based on fund's holdings to estimate fund performance. On anassociated note, Daniel and Titman (1997) discovered that stock features do better than factor loadings in explaining the cross-sectional behavior of average returns.Karceski's (1998) model suggests that funds favour growth stocks over value stocks. Chan, Karceski, and Lakonishok (2000) offerconfirmation on the functioning performance of size-value equity asset classes.

\section{Research Objective}

- To explore the schemes specificattributes which affect the mutual fund performance. 
Towards Excellence: An Indexed, Refereed \& Peer Reviewed Journal of Higher Education /

Ms. Kiran Khinchi \& Dr. Monty Kanodia/ Page 43-51

- $\quad$ To explore the macro economic factors which affect the mutual fundperformance.

\section{Schemes specific factors affecting Mutual Funds Performance:}

There are many factors that are affecting the performance directly or indirectly. Being an individual who want to invest in mutual fund he/she should first analyses the characteristic of the scheme carefully. Although, there is no such condition or we can say system by which one can be $100 \%$ sure about the future risk and trace the future movement of the fund. But to some extend one can predict the future return and risk. There are many internal and external factors by which an investor evaluates the performance of a particular fund. Below are some factors that one should go through before investing:

> Risk ReturnAdjustedParameters:Black, Jensen, and Scholes (1972) enhanced the accuracy of the CAPM by assessing beta by working with portfolios somewhat than individual assets. The valuation was made not only for the price of a single asset, but also for the price of a portfolio of assets. Jensen (1968) pointed out that a time series regression test would test the accuracy of the investment pricing model. Their evaluation took into account the CAPM parameters and their estimate and concluded that the regression analysis would provide the estimate that would be used in the model. The actual returns would then be likened to the estimates generated from the model. The significance test showed that beta was important in explaining the changes by explaining changes in expected returns and estimates falling in the range that was close to actual returns.

> Expense Ratio: The continued success of actively managed funds, despite their consistently negative administrative capacity and high expenditure rates, is a mystery (Gruber, 1996). The positive debt-to-finance ratio of advertising spend, branding, and circulation capacity (Sirri and Tufano, 1998) supports this argument. Alternatively, it is argued that investors do not know the amount of fees charged (Barber et al., 2005) and cannot see that the average active fund has a significantly lower return than an after-fee fund. inexpensive indexing.

> Past Performance: The most important mutual funds variable has been thepast performance among all fund characteristic (Siri \& Tufano, 1998). Past performance effect on the present performance of the fund has been named as "performance persistence". In (1992 Grinblatt and Titman) found that $1 \%$ abnormal return in first 5 year expected $0.28 \%$ and greater abnormal return in next 5-year period. Short persistence in performance found by (Hendricks, Patel, and Zeckhauser in 1993).

$>$ Flow of Fund:Fund flow is the sum of all cash inflows/outflows from and into different financial assets. Fund flow is usually calculated on a monthly or quarterly basis; no account is taken of the output of an asset or fund. It is only the share redemptions or outflows, and share purchases or inflows.

Size of the fund (AUM):Mutual fund size can influence the performance in numerous ways. In terms of economies as well as diseconomies of scale. Chen, Hong, Huang, and Kubik (2004) argued that economies of scale could be due to lowering of expense ratio and 
Towards Excellence: An Indexed, Refereed \& Peer Reviewed Journal of Higher Education /

Ms. Kiran Khinchi \& Dr. Monty Kanodia/ Page 43-51

administrative costs. While diseconomies of scale could be due to the organizational complexity and inability to trade without giving aindicator in the market.

Portfolio Turnover ratio:Portfolio turnover ratio reflects the level of active commercial policy of equity funds. Redirect the impact on the performance of an active trading strategy. It is directly related to the rate of expenditure of the company. In 1997, Carhart saw anadverse effect of the portfolio turnover ratio on mutual fund performance.

Cash ratio: The cash ratio is the ratio of cash and cash equivalents to the total assets under management of an investment fund. The liquidity ratio of an investment fund can affect performance as there may be liquidity bottlenecks. Babalos et al. (2009) showed a negative effect of the cash ratio on the performance of investment funds.

Age of Fund:The age of the fund or investment plan corresponds to the existence of the investment fund in years. On the stock market, funds acquire an unlimited number of years of experience. Older funds work better than newer funds because of the "learn by doing" effect. On the other hand, new funds can be more linked and therefore perform better. In the United States, Chen et al. (2004) showed no correlation between age and fund performance. In contrast, Otten and Bams (2002) found a positive correlation between baseline age and performance in five European countries. Babalos et al.

Market Timing: It takes the simple form that the investment manager either forecasts that the stock market will provide a greater return than riskless securities. The forecaster does not attempt to predict, or is not able to predict, by how much stocks will achieve better or worse than riskless securities, but $\mathrm{s} /$ he will fine-tune the relative proportions of the market portfolio and riskless securities that are held in the fund.

> Investment Styles:Fund preference for one investment style over another (for behavioural or agency reasons) can have an impact on the asset price structure. Barberis and Shleifer in 2000 showed how the search for styles by funds can explain the trends observed in the returns of stocks. For example, if funds favour a style and assign more resources to that style than the underlying fundamentals warrant, prices of stocks in that style category may temporarily deviate from fair values.

Figure 3. Factors to Considered Before Selecting a Fund 


\section{Factors To Consider While Selectin A Mutual Fund Category}

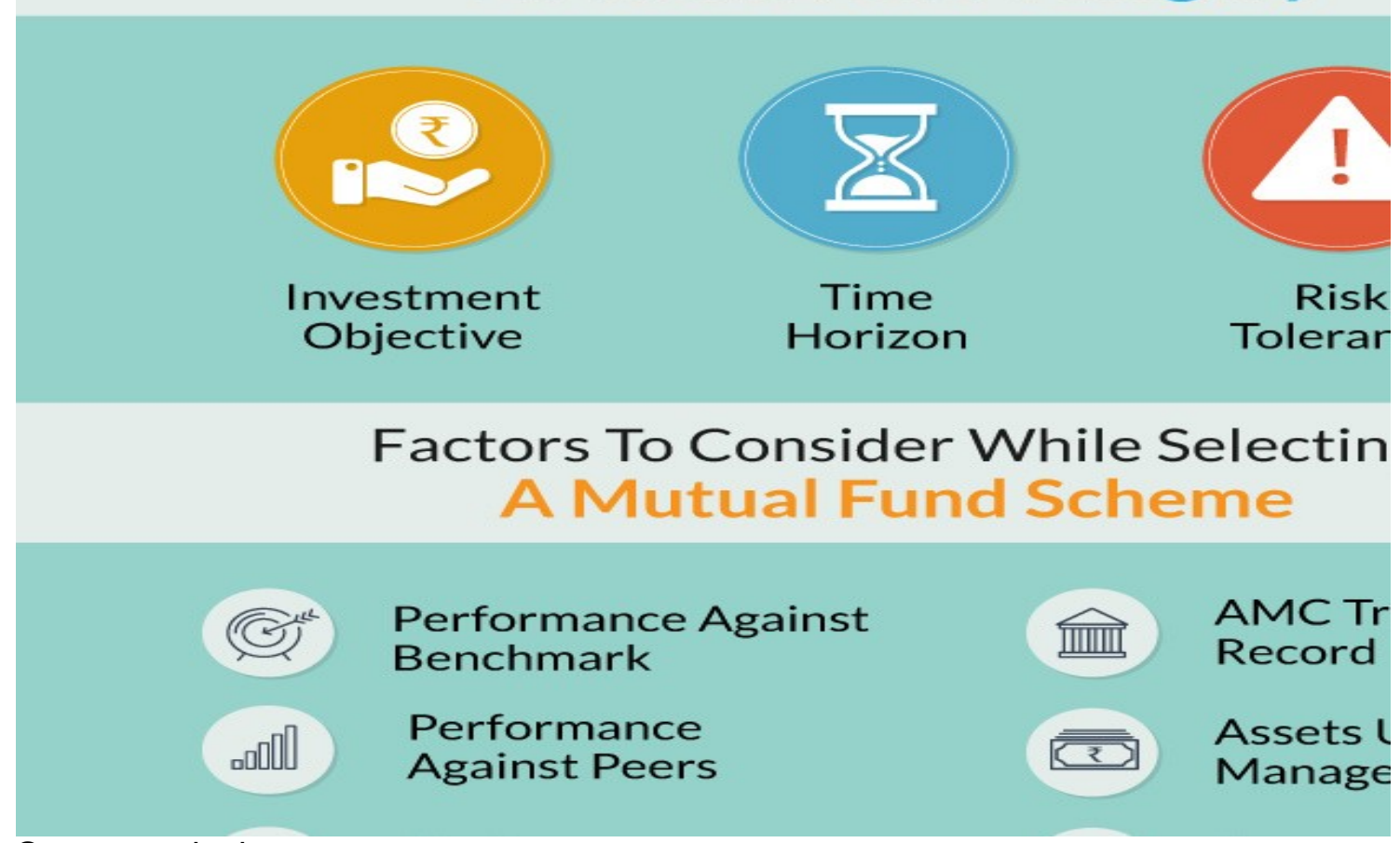

Source: paisabazaar

7. Macro-economic variables affecting the mutual fund performance:

Likewise schemes specific factors there are many macro-economic factors or we can say external factors that influence the returns and performance of mutual fund.The macro economic factors that impact the behaviour of inflows and outflows into the mutual fund schemes includelnflation, GDP, crude oil price, Exchange rate, MIBOR, G-securities, Foreign exchange reserve.

\section{Relevance of study}

The undertaken research will be helpful in the following areas:

- $\quad$ Simplifies mutual funds professionals, investors and researchers.

- Supports the professionals to take managerial, operational decision efficiently.

\section{Conclusion}

The major aim of this study is to study and explore the schemes specific and macroeconomic variables which directly or indirectly affecting the mutual fund performance. Many research articles and paper has been reviewed that showed the factors or explored the

factors or attributes which are influencing the performance. There are many scheme specific factors like Age of fund, Expense Ratio, Portfolio Ratio, Market timing, Stock selection, Managerial turnover, Risk-returns parameters, Cash flow, Fund Flow, past performance, family sizeetc. which are affecting the performance of mutual fund. Similarly, there are many 
macro-economic factors also like GDP, Inflation, Foreign Exchange reserves, Government policy, G-Sec., Interest rates, Crude oil rates etc. Many literature has concluded that Expense ratio, size of fund (AUM), Risk return parameters has a positive impact on fund performance. And coming to macro-economic factors Interest rates and G-sec. shows a positive association. 


\section{Reference}

Babalos, V., Kostakis, A., \&Philippas, N. (2009). Managing mutual funds or managing expense ratios? Evidence from Greek fund industry. Journal of Multinational Financial Management, 19(4), 256-272.

Carhart, M. M. (1997). On persistence in mutual fund performance. The Journal of Finance, 52(1), 57-82

Chen, J., Hong, H., Huang, M., \&Kubik, J. D. (2004). Does fund size erode mutual fund performance? The role of liquidity and organization.American Economic Review, 94, 12761302.

Grinblatt, M., \& Titman, S. (1994). A study of monthly mutual fund returns and performance evaluation techniques. Journal of Financial and Quantitative Analysis, 29(3), 419-444.

Grossman, S., \&Stigliz, J. (1980). On the impossibility of informationally efficient markets. American Economic Review, 70, 393-408.

Grubber, M. J. (1996). Another puzzle: The growth in actively managed mutual funds. Journal of Finance, 51(3), 783-810.

Hendricks, D., Patel, J., \&Zeckhauser, R. (1993). Hot hands in mutual funds: Short run persistence of relative performance. Journal of Finance, 48, 93 -130.

Otten, R., \&Bams, D. (2002). European mutual fund performance. European Financial Management, 8(1), 75- 101

Sharpe, W. F. (1966). Mutual fund performance. Journal of Business, 39, 119-138.

Sirri, E., \&Tufano, P. (1998). Costly search and mutual fund flows. The Journal of Finance, 53, 1589-1622.

\section{Miss. Kiran Khinchi Research Scholar, IIS (Deemed to be) University, Jaipur \\ $\&$ \\ Dr. Monty Kanodia \\ Sr. Assistant Professor, IIS (Deemed to be) University, Jaipur}

